\title{
Internally Generated Revenue (IGR) and Effectiveness of University Administration in Nigeria
}

\author{
Felicia I. Ofoegbu ${ }^{1} \&$ Hezekiah O. Alonge ${ }^{1}$ \\ ${ }^{1}$ Department of Educational Management, Faculty of Education, University of Benin, Benin, Nigeria \\ Correspondence: Hezekiah O. Alonge, Department of Educational Management, Faculty of Education, \\ University of Benin, Benin City, Nigeria. Tel: 234-803-819-1012. E-mail: hezekiah.alonge@uniben.edu
}

Received: January 13, 2016

Accepted: February 5, $2016 \quad$ Online Published: February 23, 2016

doi:10.5539/jel.v5n2p1

URL: http://dx.doi.org/10.5539/jel.v5n2p1

\begin{abstract}
The purpose of the study was mainly to identify the major sources and utilization of internally generated financial revenue by Nigerian University administrators. The population of the study consisted of all the 102 university administrators from the seventeen Federal Universities in Southern Nigeria. Descriptive statistics and Pearson Product Moment Correlation were used to analyze the research questions and hypotheses formulated for the study. The analysis revealed that commercial ventures were among the main sources of IGR while the proceeds were used for services including staff welfare, maintenance of facilities and beautification of the university premises. A further analysis of data showed that there was a significant relationship between internally generated resources and the management and development of universities in Southern Nigeria. It is recommended that university administrators should be more transformative in their leadership style in order to strengthen their revenue base for effectiveness in University management.
\end{abstract}

Keywords: effectiveness, internally generated revenue, university administration

\section{Introduction}

Worldwide, it is generally held that all stakeholders in education, including Governments, individuals and communities expect schools at all levels to produce educated persons for national and individual development. This expectation is higher at the University level which by its nature is expected to produce very high level quality manpower both for its educating functions and meeting the needs of the society for effective growth and development of every sector of the economy. It is also acknowledged that apart from the human resources, among the several factors which contribute to the achievement of the goals and objectives, adequacy of funding has been identified as possibly the most crucial in maintaining and improving the quality of education (Idialu \& Idialu, 2012). Despite the identification of funding as the key factor in positive transformation of the education most African Governments including Nigeria, and in particular, those persons in charge of education have not given explicit attention to funding the education industry.

Undoubtedly the financial challenge facing university education in Nigeria is gross under funding which could be linked to undue reliance on Government for funds by university managers (Erhagbe, 2014). Such inadequacy of funding could also be linked to the depression in the country's economy as well as the high level of corruption in the country. Hence, despite the obvious and enormous financial resources accruing to the country, the educational system is confronted with excessive inadequacy of infrastructure and facilities for teaching and research which have remained a clog in the wheel of effective administration of Nigerian Universities (Aina, 2002). The situation put the management of universities under undue stress (Nwadiani \& Ofoegbu, 2005) and as a result they are incapacitated in transforming the universities towards effective teaching, research and community services. Likewise the management could hardly embark on capital or other palpable development of their institutions; a situation which in turn has adversely affected capacity building and total development.

Indeed most basic facilities such as public address systems, interactive boards and video conferencing facilities which are taken for granted in many more developed foreign institutions of learning are either unavailable or in short supply in Nigeria. Ogbogu (2011) stated in his study that the academic staff did not attend workshops and conferences regularly and that there was a drastic reduction in the award of research grants and fellowships all due to lack of funds. 
Table 1. Annual budgetary allocation on education

\begin{tabular}{llll}
\hline S/No. & Country & \% Budget Allocation to Education & Position \\
\hline 1 & Ghana & 31.0 & $1^{\text {st }}$ \\
2 & Cote d' lvore & 30.0 & $2^{\text {nd }}$ \\
3 & Uganda & 27.0 & $3^{\text {rd }}$ \\
4 & Morocco & 26.4 & $4^{\text {th }}$ \\
5 & South Africa & 25.8 & $5^{\text {th }}$ \\
6 & Swaziland & 24.6 & $6^{\text {th }}$ \\
7 & Mexico & 24.3 & $7^{\text {th }}$ \\
8 & Kenya & 23.0 & $8^{\text {th }}$ \\
9 & United Arab Emirate & 22.5 & $9^{\text {th }}$ \\
10 & Botswana & 19.0 & $10^{\text {th }}$ \\
11 & Iran & 17.7 & $11^{\text {th }}$ \\
12 & USA & 17.1 & $12^{\text {th }}$ \\
13 & Tunisia & 17.0 & $13^{\text {th }}$ \\
14 & Lesotho & 17.0 & $14^{\text {th }}$ \\
15 & Burkina Faso & 16.8 & $15^{\text {th }}$ \\
16 & Norway & 16.2 & $16^{\text {th }}$ \\
17 & Colombia & 15.6 & $17^{\text {th }}$ \\
18 & Nicaragua & 15.0 & $18^{\text {th }}$ \\
19 & India & 12.7 & $19^{\text {th }}$ \\
20 & Nigeria & 8.4 & $20^{\text {th }}$ \\
\hline
\end{tabular}

Source: World Bank, 2012

Table 1 reveals World Bank (2012) report on the annual budgetary allocation to education for 20 countries. The table shows Nigeria at the bottom of the table with $8.4 \%$ allocation to education with Ghana occupying the first position with $31.0 \%$ allocation to education.

Kpolovie and Esezi (2013) affirmed that over the years the Nigerian governments' budgetary allocations for education have left much to be desired. According to the authors the allocation trend is abysmally retrogressive; a trend that has the tendency to destroy all that is positive in education. Abayomi (2013) affirmed that the highest budgetary amount appropriated to education and by inference the tertiary institutions was $10 \%$ in 2013 .

The Federal Government of Nigeria (2012) worried about the incessant complaints of poor funding of public institutions of learning advised university managers through the National Universities Commission (NUC) to explore various ways of generating ten percent (10\%) of their expected revenue from within and outside their institutions towards solving their finance related problems rather than depend almost entirely on subsidizations by Government. Several institutions of learning especially the higher institutions are already capitalizing on the Federal Government directive. Some university managers have devised means of generating extra revenue towards meeting the developmental needs of their institutions. Indeed evidence abound of such revenue drive and the most obvious are the commercial ventures. 
Table 2. Total government grant and IGR in Federal Universities

\begin{tabular}{llll}
\hline Institution & Total Releases (Rec. \& Cap) & IGR & \% of IGR in total income \\
\hline IBADAN & $2,509,890,696$ & $196,575,448$ & 7.8 \\
LAGOS & $1,955,127,150$ & $359,502,258$ & 18.4 \\
NSUKKA & $2,512,793,291$ & $98,141,298$ & 3.9 \\
ZARIA & $2,567,587,409$ & $73,210,330$ & 2.6 \\
IFE & $2,304,114,896$ & $40,031,187$ & 1.7 \\
BENIN & $1,949,126,834$ & $155,172,513$ & 8.5 \\
JOS & $1,332,790,023$ & $48,744,424$ & 3.7 \\
CALABAR & $1,227,113,25$ & $105,939,905$ & 8.8 \\
MAIDUGURI & $1,089,098,496$ & $137,148,440$ & 12.6 \\
SOKOTO & $651,927,799$ & $39,025,328$ & 6.0 \\
ILORIN & $1,472,655,002$ & $65,616,425$ & 4.5 \\
PORT-HACOURT & $1,268,403,040$ & $110,415,425$ & 8.7 \\
ABUJA & $402,154,078$ & $84,674,826$ & 21.1 \\
UYO & $1,013,481,643$ & $86,476,190$ & 8.5 \\
AKWA IBOM & $801,835,93$ & $34,697,558$ & 4.4 \\
OWERRI & $611,326,365$ & $29,751,258$ & 4.9 \\
AKURE & $545,315,202$ & $35,855,281$ & 6.6 \\
MINNA & $417,130,171$ & $20,549,000$ & 5.5 \\
BAUCHI & $556,280,147$ & $17,268,097$ & 3.1 \\
YOLA & $499,590,326$ & $21,962,043$ & 4.4 \\
TOTAL & $\mathbf{2 6 , 6 6 9 , 5 4 4 , 0 6 0}$ & $\mathbf{1 , 8 1 5 , 1 7 6 , 6 2 7}$ & $\mathbf{6 . 8}$ \\
\hline
\end{tabular}

Source: NUC (2003)

Key: IGR-Internally Generated Revenue

\section{Literature Review}

This study is hinged on the theory of transformational leadership which asserts that the focus of leadership ought to be the commitment to organizational goals and objectives as well as greater capacity for accomplishing those goals and therefore greater productivity (Leithwood, 1994). It is also expressed as a process of interaction between a leader and the followers in such a way that it leads to positive transformation of the organization.

Internally Generated Revenue (IGR) may be in the form of Education Counterpart Funding Scheme (ECFS) which serves to fund the university system apart from the statutory grant that is received from the Government.

Erhagbe (2014) states that IGR is the creation of "tangible" and "intangible" funds within the confines of one's entity. It is a combination of all non-governmental monetary accruals to the institution and may involve diverse strategies. This means that the funds used in effectively transforming the institution's landscape were not borrowed or realized through direct Government intervention.

Wangenge-Ouma and Cloete (2008) and Okojie (2013) have observed that some tertiary institutions have done reasonably well in their drive for substantial IGR and have used it to positively change the landscape of the institutions while some were yet to catch up with the vision.

Education is the supreme instrument for national development, socio-economic, scientific and technological advancement. However, Nigeria a country with a laudable constitutional provision to ensure Government participation in financing education has never allocated up to $20 \%$ of its annual budget to education since 1960 . Records from the Central Bank of Nigeria (2012) shows that the highest annual budget allocation to the education sector was $17.59 \%$ and this was in 1997. Every other allocation made to the sector from 1960 to 2013 had been below 14\%. This implies that on the average Nigeria spent 5.7\% yearly from 1960 to 2013 on 
education which is grossly below the benchmark of $26 \%$ of the annual budgetary allocation to education (UNESCO, 2010).

\subsection{Statement of the Problem}

The cost of ensuring quality assurance in education is high. Therefore a country that wants quality education at all levels of schooling for its citizen needs to invest extensively on its planning and implementation programmes.

Undoubtedly the financial challenges facing university education in Nigeria is that of gross underfunding. It is also common knowledge that one of the fundamental reasons for incessant industrial disquiet in Nigerian universities is the agitation for better funding of the system. It is assumed that if the problem of funding is resolved most of the educational problems will be solved or reduced. Therefore it has become necessary to find out if there is any relationship between internally generated financial resources and the effective management of Nigerian universities.

\subsection{Research Questions}

(1) What are the common sources of internally generated revenue in Nigerian Universities?

(2) How do administrators of Nigerian universities utilize IGR?

(3) Is there any relationship between IGR and the development of Nigerian universities?

\subsection{Hypothesis}

Question 1 and 2 were answered while question 3 was hypothesized.

$\mathrm{Ho}_{1}$ : There will be no significant relationship between IGR and the management of Nigeria Universities.

\subsection{Objective}

The main objective of the study is to find out if any relationship exists between IGR and effective management of universities. The study is also to document some of the sources and uses of IGR that will enable university administrators confront some of the financial challenges of meeting the goals of the institutions as well as making meaningful attainment of university goals of teaching, research and learning.

\section{Methodology}

The study used the descriptive survey design. The population of the study comprises all the one hundred and two principal officers in the 17 Federal Universities in Southern Nigeria irrespective of area of specialization. All the 102 officers including the Vice Chancellors and Deputy Vice Chancellors, the Registrar, the Librarian and the Bursar, participated in the study. Each university had a maximum of six principal officers who were referred to as the Management Team of the University. Therefore no sampling was carried out.

\subsection{Instrument}

The instrument used for the study was a structured questionnaire titled "Internally Generated Revenue Management Questionnaire (IGRMQ)". The instrument was made up of four parts;

Part one was used to gather the demographic data on the respondents.

Part two sought information on the major sources of internally generated revenue.

Part three sought information on the uses of IGR.

Part four gathered information on the relationship between IGR and effective management and development of universities.

\section{Validity}

A draft of the research instrument was presented to some experienced University administrators in Southern Nigeria. They made useful corrections and suggestions which were carefully effected to give the content and face validity of the instrument.

A prior study was carried out to ascertain the level of reliability of the research instrument. The internal consistency index using a Cronbach Alpha test was thus computed and established at 0.79 . This was considered reliable enough for the study. 


\section{Analysis of Data}

Descriptive and parametric statistics were used to analyse the data collected for the study. While mean $(\overline{\mathrm{x}})$ and Standard Deviation (SD) were used to analyse data collected for research questions1 and 2, the pearson product moment correlation (pearson $\mathrm{r}$ ) statistics was used to analyse the data collected for the hypothesis formulated for the study.

\section{Results}

The results of the data analyzed are presented in the tables below.

Table 3. Mean analysis of the sources of internally generated revenue

\begin{tabular}{lllll}
\hline Sources & Mean Scores & Standard Deviation & f-value & Sig. \\
\hline Commercial ventures & 3.98 & 0.87 & 46.56 & $0.000^{* *}$ \\
Research and Consultant services & 2.96 & 1.06 & 21.06 & $0.000^{* *}$ \\
Manufacturing and processing & 2.64 & 0.94 & 9.46 & $0.002^{*}$ \\
Alumnus and Endowments funds & 2.53 & 0.92 & 6.02 & $0.040^{*}$ \\
\hline
\end{tabular}

$\mathrm{P}<0.05$

Table 3 shows that the mean scores and standard deviations of sources of internally generated resources were Commercial Ventures (Mean $=3.98, \mathrm{SD}=0.87)$, Research and Consultant services (Mean $=2.96, \mathrm{SD}=1.06$ ), Manufacturing and Processing (Mean $=2.64, \mathrm{SD}=0.94$ ) and Alumnus and endowment funds (Mean $=2.53, \mathrm{SD}$ $=0.92$ ). The calculated f-values were significant at the probability level of 0.05 . It reveals that commercial ventures followed by research and consultant services were the major sources of IGR.

Table 4. Mean and standard deviation on the responses of university administrators on the uses of IGR

\begin{tabular}{llll}
\hline Uses of IGR & Mean Scores & Standard Deviation & Sig. \\
\hline Capital projects & 1.41 & .70 & NS \\
Staff welfare & 3.54 & 1.00 & Sig. \\
Staff development & 2.83 & 1.31 & Sig. \\
Payment of salaries & 1.34 & 0.72 & NS \\
Student welfare & 2.63 & 1.79 & Sig. \\
Maintenance of facilities & 3.83 & 1.22 & Sig. \\
Furnishing of offices & 2.66 & 1.26 & Sig. \\
Beautification of university premises & 3.39 & 1.13 & Sig. \\
Furnishing and equipping e-library & 2.19 & 1.13 & NS \\
Production of electricity and water & 2.66 & 0.95 & Sig. \\
Research development & 2.98 & 1.36 & Sig. \\
\hline
\end{tabular}

The results in Table 4 show the utilization of IGR by the administrators of Nigerian universities. Data on the variables show the university administrators use IGR to carry out some projects including maintenance of facilities, staff welfare and beautification of university premises. These variables recorded the mean scores and standard deviation of 3.83, $\mathrm{SD}=1.22 ; 3.54, \mathrm{SD}=1.00$ and 3.39, $\mathrm{SD}=1.13$ respectively. Capital projects (Mean $=1.41, \mathrm{SD}=.70$ ), payment of staff salaries' (Mean $=1.34, \mathrm{SD}=.72$ ), and furnishing and equipping E-library $($ Mean $=2.19, \mathrm{SD}=1.13)$ were the least significant areas in which university administrators applied IGR. The result of the analysis reveals that university managers use internally generated resources in critical areas that are vital to the attainment of university goals and objectives. 
Table 5. Pearson " $r$ " analysis of relationship between IGR and effective management of Nigerian universities

\begin{tabular}{lccccc}
\hline \multicolumn{1}{c}{ Variable } & $\mathbf{N}$ & Pearson & “r” & Sig. & Decision \\
\hline Internally generated revenue & 102 & & & & \\
\cline { 1 - 2 } & 102 & .189 & .000 & Significant \\
\hline
\end{tabular}

$\mathrm{P}<0.05$

Table 5 reveals a calculated Pearson " $r$ " of 0.189 which is significant at $\mathrm{P}<0.05$ alpha level. Therefore the null hypothesis which states that there is no significant relationship between IGR and effective management of universities is rejected.

\subsection{Discussion}

The foregoing results attest to the sources and utilization of Internally Generated Revenue. According to the managers of Nigerian universities funds are generated mainly through commercial ventures like rental of shops, running of hotels, guest houses, petrol stations and bakery and manufacture of table water. The findings correlate with those carried out by Adeniyi (2008) and Okojie (2010). Teaching and learning require an enabling environment which calls for adequate funding for the maintenance of facilities as well as addressing staff and student welfare matters, developmental issues and research.

The justification of IGR is underpinned by the fact that government priority for education is rather low while the fund provided is inadequate. The results of the study indicated that there was need for internally generated revenue to achieve the objectives and goals of the university system. The continuous gross underfunding of the educational system particularly the universities is one of the seemingly intractable problems facing the university education in Nigeria (Erhagbe, 2014). Therefore there should be no half measures in pursuing IGR and its implementation. In today's knowledge driven society and especially in Nigeria, where budgetary allocation to Education is grossly inadequate IGR will tend to close the gap and so promote the quality, productivity and efficiency of higher educational institutions.

If university leadership is to address frontally the problem of underfunding of the institutions of higher learning it should tap from the intangible resources that accrue from commercial ventures, research and consultancy services, manufacturing/fabrication of tools and other sources of internally generated revenue in order to achieve tangible/visible transformation in the infrastructural landscape of the institutions. This will further translate to meaningful achievement of the tripodal roles of the university system namely teaching research and community services.

\subsection{Conclusion}

The result shows that a large majority of university administrators are of the opinion that IGR will reduce the problem of underfunding and over reliance on government for funds the scarcity of which has remained a clog in the wheels of effective management of university education in Nigeria. It also shows that IGR if properly executed will ensure positive transformative changes with a propensity for more progress. Therefore based on the findings of this study it can be concluded that commercial ventures were the major sources of IGR. The consequences of IGR in effective administration amidst scarce and dwindling resources (finance) on varied educational transactions are highlighted in Table 2 and conclude with a review of the implications of the inherent trends for university management. In fact, there is a significant relationship between IGR and university administration in Nigeria.

\subsection{Recommendation}

Since IGR serves the interest of educational instructions it must be set up to actualize the ideals of university education. The following recommendations are therefore made:

i) The funds which are generated internally by the universities need to be managed judiciously to achieve a holistic development of the university.

ii) In this age where corruption and greed are rife, where the policy of the winner takes all is shamelessly practiced university leadership must shelve such vices and demonstrate greatness in the management of such resources. A great leader does not wallow in complaints and lamentations. Rather he must be focused and capable; he must be a visionary and able to demonstrate great competence and resourcefulness and be a deft administrator. Simply put he must be an honest and transformational leader. 
iii) In the management of such funds a major problem is finding the ability to manage them effectively. This may be achieved either by appointing a special committee to run the yielding enterprises under the auspices of the Vice Chancellor and members of the governing council or incorporating a limited liability company to administer such internally generated revenue.

iv) The concept of Return on Investment based on performance should be employed by the management in order to identify the sources that might need expansion.

v) University management could as an alternative to (iv) above create an IGR coordination centre. The office will support the relevant money generating units. This will ensure that serious attention is given to IGR areas for effectiveness and efficiency. It will also ensure that long bureaucratic bottlenecks are reduced or eliminated. Such a unit should relate directly to the Vice Chancellor's office.

vi) There may be need for the university managers to engage the services of internal and external Auditors to ensure that the accounts presented by those that handle the various commercial ventures reflect the true positions of the business transactions.

The university management needs to closely monitor and supervise these ventures to ensure accountability and profitability. The proceeds from the ventures can then be effectively utilized to enable qualitative university education. It is advisable that university administrators adopt transformational leadership style based on improvement of staff and student welfare while not neglecting infrastructural development through prudent management of the resources.

\section{References}

Abayomi, A. (2013). Education budget and its implications (Analysis). Vanguard Newspaper.

Adeniyi, P. O. (2008). Repositioning Nigerian Universities for national sustainable development. A paper presented at the $10^{\text {th }}$ Iju Quarterly Public Affairs Forum Series, Ondo State, Nigeria.

Aina, O. I. (2002). Alternative modes of financing higher education in Nigeria and implications for university governance. In J. B. Babablola, \& B. O. Emunemu (Eds.), Issue in higher education, research evidence from Sub-Saharan Africa. Lagos, Bolabay Publications.

Ayo-Sobowale, M., \& Akinyemi, S. (2011). Funding Strategies for Quality University Education in Nigeria: The Principle of Fiscal Justice. Journal of Studies in Education, 1(1), 11.

Central Bank of Nigeria. (2012). Retrieved from http://www.nigeriagov.ng

Eragbe. (2014). University education financing in Nigeria: Using Oshodin's strategy to convert intangible to tangible development. In E. O. Ojeme, \& L. I. Salami (Eds.), Transformational Leadership in the University of Benin. A publication of the Faculty of Education, University of Benin, Benin City.

Federal Government of Nigeria. (2012). The Nigerian office and evaluation sector report. Federal Ministry of Education, Abuja.

Idialu, J. O., \& Idialu, E. E. (2012). Entity, ownership, educational subsidies and funding of Nigerian tertiary institutions: Current research. Journal of Social Sciences, 4(1), 56-61.

Kpolovie, P. J., \& Esezil, O. (2013). Adequacy-inadequacy: Education funding in Nigeria. Universal Journal of Education and General Studies, 2(8), 239-254.

Leithwood, K. (1994). Leadership for School Restructuring. Educational Administration Quarterly, 30(4), 498-518. http://dx.doi.org/10.1177/0013161X94030004006

Nwadiani, M., \& Ofoegbu, F. (2005). Level of Perceived Stress Lecturers in Nigerian Universities. Journal of Instructional Psychology, 33(1), 66-74.

Ogbogu, C. O. (2011). Modes of Funding Nigerian Universities and the Implications on Performance. A paper presented at the 2011 Barcelona European Academic Conference, Spain.

Okojie, C. O. (2010). Systems and strategies for funding Nigerian Universities. A paper presented at a lecture on innovative and administrative effectiveness of university administrators in Nigeria.

Onuoha, L. O. (2013). Financing Higher Education in Nigeria: The Role of Internally generated revenues and how University Management can maximize the sources.

UNESCO. (2010). Education for all global monitoring report. UNESCO. 
Wangenge-Ouma, G., \& Cloete, N. (2008). Financing higher education in South Africa: Public funding, Non Government revenue and tuition fees. South African Journal of Higher Education, 22(4), 906-919.

World Bank. (2012). Selected 20 countries annual budgetary allocations to education. Washington D.C.

\section{Copyrights}

Copyright for this article is retained by the author(s), with first publication rights granted to the journal.

This is an open-access article distributed under the terms and conditions of the Creative Commons Attribution license (http://creativecommons.org/licenses/by/3.0/). 